\title{
Situs Sunan Rejodanu Desa Pucang Rejo Kecamatan Sawahan Kabupaten Madiun Sebagai Wisata Sejarah Dan Religi
}

\author{
Imelda Eka Aprilia, Anjar Mukti Wibowo* \\ Universitas PGRI Madiun \\ *Corresponding author`s e-mail: anjarmuktiwibowo@unipma.co.id
}

\begin{abstract}
This study aims to reveal the profile of Sunan Rejodanu, identify historical relics at the Sunan Rejodanu site in Pucangrejo Village, Sawahan District, Madiun Regency and analyze their potential as historical and religious tourism. The results showed that Sunan Rejodanu or Muhammad Nur Ali Zaen came from Rembang, Central Java, who came to Madiun to find his younger brother who disappeared after the Java war. In Madiun, Sunan Rejodanu studied and studied Islam and was given the title Sunan. The teacher was assigned to the boarding school organization and was able to bring about big changes, but the cottage was destroyed and the mosque was destroyed due to flash floods. The remaining remains of Sunan Rejodanu are the tomb, the kejen stone sacred by the local community, and a well. The Sunan Rejodanu site has another name that attracts attention, namely the Anti-Middle River Tomb, in addition to the figure and the historical life journey of Sunan Rejodanu. Religious traditions are also still strong at the Sunan Rejodanu Eating Site, so they have the potential for historical tourism and religious tourism.
\end{abstract}

Keywords: Site, Sunan Rejodanu, Historical tours

Abstrak: Penelitian ini bertujuan untuk mengungkap profil Sunan Rejodanu, mengidentifikasi peninggalan-peninggalan sejarah di situs Sunan Rejodanu di Desa Pucangrejo, Kecamatan Sawahan, Kabupaten Madiun dan menganalisis potensinya sebagai wisata sejarah dan religi. Hasil penelitian menunjukkan Sunan Rejodanu atau Muhammad Nur Ali Zaen berasal dari Rembang Jawa Tengah yang datang ke Madiun untuk mencari adiknya yang hilang pasca perang Jawa. Di Madiun, Sunan Rejodanu belajar dan menyebarkan agama Islam dan diberi gelar Sunan. Oleh gurunya ditugasi mengelola pondok pesantren dan mampu membawa perubahan besar, namun pondok tesebut hancur beserta masjidnya karena banjir bandang. Peninggalan Sunan Rejodanu yang tersisa adalah makam, batu kejen yang disakralkan oleh masyarakat setempat, dan sumur. Situs Sunan Rejodanu memiliki nama lain yang menarik perhatian, yaitu Makam Antik Tengah Sungai, disamping sosok dan perjalanan hidup Sunan Rejodanu yang menyejarah. Tradisi keagamaan juga masih kuat di Situs Makan Sunan Rejodanu sehingga potensial sebagai wisata sejarah dan wisata religi.

Kata kunci: Situs, Sunan Rejodanu, Wisata sejarah

\section{Pendahuluan}

Kenyataan Kabupaten Madiun merupakan sebuah daerah yang terletak di Provinsi Jawa Timur. Kabupaten Madiun merupakan daerah strategis yang berada pada perlintasan yang menghubungkan Surabaya menuju ke Yogyakarta dan sebaliknya. Wilayah Madiun dialiri sungai-sungai besar, yaitu Bengawan Solo dan Bengawan Madiun. Kedua aliran bengawan tersebutbertemu di Kota Ngawi dan wilayah Madiun bagian ujung Utara. Ribuan tahun yang lampau bengawan (sungai) berfungsi sangat besar sebagai sarana kehidupan manusia-manusia purba. Hal ini terbukti bahwa di sekitar bengawan tersebut banyak ditemukan peninggalan-peninggalan purba (Pemkab Madiun, 1980). Kabupaten Madiun 
memiliki cukup banyak peninggalan sejarah. Di setiap Kecamatan dan desa mempunyai cerita sejarah tersendiri. Di salah satu Kecamatan dan desa yang ada di Kabupaten Madiun mempunyai sejarah yang unik dan sebagian warga di Kabupaten Madiun belum pernah mendengar ataupun tahu tentang sejarahnya. Peninggalan sejarah tersebut adalah Situs Sunan Rejodanu yang berada di Kecamatan Sawahan Desa Pucangrejo. Masa sejarah merupakan zaman dimana manusia sudah mengenal adanya tulisan. Terlihat munculnya peninggalan-peninggalan sejarah seperti tulisan atau ukiran di batu dan tempat-tempat bersejarah. Di wilayah Madiun tersebut juga banyak terdapat peninggalan-peninggalan sejarah dulu kala yang tersebar dibeberapa tempat, antara lain seperti prasasti Klagen Serut, Prasasti Mruwak, Situs Candi Wonorejo, Situs Ngurawan dan juga situs-situs lainnya (Habsari, 2016). Situs yaitu suatu tempat yang dianggapmenyimpan benda-benda cagar budaya serta lingkungan yang dibutuhkan untuk perlindungannya situs sejarah berkaitn langsung dengan peninggalan-peninggalan sejarah yang di sebut sebagai warisan budaya yang melibatkan situs cagar budaya yaitu tempat yang menyimpan bangunan-bangunan caragar budaya dan juga menyimpan aktivitas manusia pada masa dahulu kala.

Situs sejarah adalah wilayah ditemukan peninggalan purbakala.Peninggalanpeninggalan purbakala tersebut sepertikerajaan, tempat keramat, candi, arca, dan tempat beribadah. Hal tersebut dapat diperlihatkan pada masa sekarang bahawa peninggaanpeninggalan masa lalu bisa disebut dengan sejarah. Dengan begitu bahwa situs sejrah tersebut penting dipelajari dan dipahami oleh generasi milenial. (Soebijantoro, 2016). Peninggalan-peninggalan sejarah yang berada dekat sungai seperti di situs Sunan Rejodanu tersebut ialah sumur yang sudah terendam air sungai, dan di dekat tangkis sungai terdapat Makam Sunan Rejodanu yang dikenal oleh masyarakat sekitar dengan sebutan Makam Antik di tengah sungai. Keberadaan situs Sunan Rejodanu menarik untuk diteliti agar bisa dikenal oleh orang banyak dan diapresiasi oleh masyarakat luas.

Sunan Rejodanu berasal dari Rembang, Jawa Tengah.Sunan Rejodanu sampai di Jawa Timur karena diutus untuk mencari adiknya yang mencari perlindungan pada saat Perang Jawa atau Perang Diponegoro (1825-1830). Setelah Pengeran Diponegoro ditangkap oleh Kolonial Belanda, para prajuritnya berpencar, termasuk adik Sunan Rejodanuatau dikenal juga dengan nama Kyai Ageng R.H. Muhammad Nur Ali Zain, yaitu Raden Mas Tumenggung Muhammad Nur Ali Imron. Muhammad Nur Ali Zain mendapatkan informasi bahwa adiknya berada di Madiun, sehingga ia mencarinya ke Madiun yaitu di Ngelambangan Wungu. Iajuga mendapat informasi bahwa adiknya belajar ilmu agama sampai ke Rejodanu atau sekarang Desa Pucangrejo. Akhirnya Sunan Rejodanu dan adiknya bersama-sama belajar ilmu agama di daerah tersebut. Nama atau gelar Sunan Rejodanu sendiri diberikan 
oleh gurunya untuk Muhammad Nur Ali Zain, sehinggabukan dari kewalian. Makam Sunan Rejodanu tidak banyak dikenal masyarakat karena menghindari dari buruan penjajah dengan melepaskan gelarnya untuk sementara(wawancara Kiai Ali Said). Keberadaan situsSunan Rejodanu menarik untuk diteliti terkait dengan sosoknya, peninggalan-peninggalan sejarah yang ada di situs Sunan Rejodanu dan sejarah serta perkembangan situs Sunan Rejodanu. Tujuan penelitian untuk mendeskripsikan dan mengidentifikasi peninggalan-peninggalan sejarah situs Sunan Rejodanu serta menganalisisnya sebagai wisata sejarah dan religi.

\section{Metode}

Penelitian Penelitian ini ialah penelitian kualitatif deskriptif. Sumber-sumber yang digunnakan adalah data primer dan sekunder. Data Primer merupakan data pertama atau data wajib yang digunakan dalam penelitian. Data pokok dideskripsikan merupakan model data yang didapatkan melalui subyek utama penelitian ataupun informan. Dari pengertian tersebut dapat disimpukan bahwa pengumpulan data primer berkaitan komunikasi langsung atau kontak antara peneliti dan informan (Sidiq, 2018). Peneliti melakukan wawancara dengan informan utama yang memahami betul tentang Situs Sunan Rejodanu dan bertemu secara langsung, agar peneliti mendapatkan sebuah informasi yang akurat dan asli. Data sekunder merupakan data pelengkap yang didapatkan selain dari informan pihak pertama, melainkan diperoleh dari tangan kedua, ketiga atau seterusnya berupa buku-buku sejarah, diarsipkan dari juru kunci, dan arsip keluarga silsilah Sunan Rejodanu.

Teknik sampling yang digunakan dalam penelitian ini merupakan snawball sampling. Peneliti memilih informan kunci yang memiliki pengetahuan dan pemahaman tentang situs Sunan Rejodanu. Selanjutnya pemilihan informan bergulir berdasarkan informasi dari sumber pertama tersebut. Penelitian ini dilakukan dengan tiga teknik pengumpulan data sebagi berikut. Analisis data yang digunakan adalah analisis interaktif, yaitu Reduksi Data, Penyajian Data dan Penarikan Kesimpulan.

\section{Hasil Dan Pembahasan}

\section{A. Hasil Penelitian}

\section{Kondisi Umum Situs Sunan Rejodanu}

Dahulu kompleks makam Mbah Alizen atau yang dikenal dengan makam Sunan Rejodanu agak jauh dari sungai, karena makamnya berada di Barat surau. Di Timur surau ada Pondok Pesantren Rejodanu dan di sebelah Timur pondok pesantren mengalir Bengawan Madiun. Fungsi sungai saat itu selain untuk mandi para santri juga sebagai air wudhu. Menurut cerita para sesepuh, konon dahulu kala ada beberapa ekor burung sedang melintas terbang diatas makam Sunan Rejodanu terjatuh tanpa diketahui sebabnya. Peristiwa tersebut 
terjadi berkali-kali dan aisaksikan oleh para sesepuh yang sedang melewati makam/sedang ziarah, serta oleh pencari rumput di sekitar makam (Ali Said, 2015). Wilayah tersebut sering kebanjiran dan terkena erosi (pengikisan tanah oleh air) lahan Pondok Pesantren Rejodanu dan surau semakin sempit, hingga hancur dan hilanglah Pondok Pesantren. Surau Rejodanu pun di terjang banjir.Kini yang tertinggal hanya Makam Sunan Rejodanu, makam kerabatnya dan makam para keturunannya. Yang terakhir di makamkan di Pesarean Rejodanu adalah Kyai Muhammad Thoyiban (buyut Sunan Rejodanu) pada tahun 1983 M.

\section{Profil Sunan Rejodanu}

Kisah Sunan Rejodanu berawal dari 3 orang laki-laki bersaudara, yaitu Danu Ismuyo, Danu Ismadi, Danu Rejo. Ketiganya diminta oleh gurunya untuk lelaku, yaitu mengasah olah batin dengan ngaji alam/ngaji laku sambil berdakwah. Ketiganya berbulanbulan menyusuri sungai Madiun dan singgah di sebelah Barat sungai. Tanpa disengaja, tanah tersebut sesuai dengan ciri-ciri petunjuk dari gurunya untuk tempat tinggal. Karena banyak para Danu di daerah tersebut, maka orang-orang dan daerah sekitarnya menamakan Kampung Rejodanu. Danu Ismuyo dan Danu Ismadi meninggal sebelum Perang Jawa. Pada saat Perang Diponegoro yang di kenal dengan Perang Jawa tahun 1825-1830 M, Danu Rej ikut berperang secara bergerilya. Setelah Pangeran Diponegoro dan Panglimanya yaitu Raden Bagus Sentot Ali Basyah Abdul Mustopo Prawirodirjo ditangkap oleh Belanda, maka prajuritnya terpencar-pencar. Di antara prajuritnya yang berpangkat Tumenggung yaitu R.M. Tmg. Muhammad Nur Ali Imron.Ia sampai di Rejodanu untuk menyusun sebuah kekuatan yang didukung oleh Danu Rejo dan diangkat menjadi santrinya.

Untuk melindungi diri, maka ia menyembunyikan identitas dengan melepaskan gelar Tumenggungnya (setingkat menteri) dan berganti nama Ali imron, tetapi orang-orang menyebutnya Mbah Imran. Selama di Rejodanu, Ali Imron dan prajuritnya yang masih setia, digembleng oleh Danu Rejo dengan memperdalam ilmu agama, ilmu kanuragan (kesaktian), olah batin (ketajaman hati) dan olah krida (siasat perang). Pihak Belanda menyebarkan Telik Sandi (mata-mata) keberbagai pelosok daerah dan menumpas sisa-sisa prajurit Pangeran Diponegoro. Setelah pihak Belanda mengetahui tempat persembunyian R.M. Tmg. Muhammad Nur Ali Imron, pasukan Belanda memburunya. Atas petunjuk Danu Rejo bahwa Belanda akan menyerang, maka Ali Imron mengumpulkan prajuritnya dan berpidato dengan berapi-api, membakar semangat prajuritnya dengan semboyan TII TI BEH: mati siji mati kabeh, mukti siji mukti kabeh (mati satu mati semua, senang satu senang semua). Ali Imron dan prajuritnya dengan semangat membara berangkat menghadang pasukan Belanda di sebelah Barat Rejodanu dengan siasat gerilya. Setelah pasukan Belanda masuk dalam perangkapnya, Ali Imron memekikkan kalimat takbir dan semua langsung menyerang. 
Mendapat serangan sangat mendadak pasukan Belanda kalang kabut dan tidak bisa menggunakan senjata bedil karena jaraknya sangat dekat. Prajurit Rejodanu bertempur matimatian dan Ali Imron tampil dengan gagah berani mangayunkan pedang dengan gerakannya yang gesit, cekatan dan tangkas.Saat ini pedang tersebut disimpan oleh salah satu keturunannya. Prajurit Rejodanu akhirnya dapat mengalahkan pasukan Belanda dan pasukan yang tersisa kocar-kacir lari tunggang-langgang, sehingga pasukan Belanda mengalami Kajoran/Kasoran (kekalahan). Akhirnya dari kata Kajoran daerah tersebut sekarang menjadi dusun Juron Desa Pucangrejo. Setelah memenangkan pertempuran, R.M. Tmg. Muhammad Nur Ali Imron dijadikan menantu oleh Palang Rejosari, yang saat itu juga membantu perjuangannya. Ia tetap menjalankan syiar Agama Islam dengan membangun masjid dan pesantren. Tanah yang agak tinggi dan di tumbuhi pohon jati, dahulunya adalah Pondok Pesantren dan Masjid pertama Rejosari, Sawahan, Madiun yang dibangun oleh R.M. Tmg.

Muhammad Nur Ali Imron.Sekarang tanah tersebut dikenal dengan sebutan sawah pondok, tepatnya di sebelah selatan kurwng lebih 300 meter dari Masjid Jami' Roudhotul Jannah Rejosari. R.M. Tmg. Muhammad Nur Ali Imron mempunyai kakak yang sangat alim yaitu R.M. K.H. Muhammad Nur Alizen. Kakaknya telah mencarinya selama bertahuntahun.Setelah mendapat kabar bahwa adiknya berada di Madiun, ia berusaha mencarinya. Pertama kali yang disinggahinya adalah daerah Ngiambangan, Wungu, Madiun.Ia mendirikan sebuah masjid dan pondok pesantren di daerah tersebut. Karena masih ada tugas untuk mencari adiknya, maka masjid dan pondok pesantrennya diserahkan kepada putra pertamanya yaitu Kyai Abdullah. Situasi penjajahan dan politik saat itu, agama sangat dibatasi ruang gerakınya sekarang tinggal sejarah. Bekas pondok pesantren dan masjid tersebut berupa tanah yang agak tinggi dan sudah menjadi gerumbul yang dikenal dengan tanah sangar oleh penduduk setempat.

Setelah sekian lama mencari, maka bertemulah kedua saudara tersebut di daerah Rejodanu. R.M. Tmg. Muhammad Nur Ali Imron diminta pulang oleh kakaknya, namun ia tidak mau, karena masih ingin syiar agama sepert para pendahulunya disamping sudah banyak santrinya. Kakaknya diantarkan ke gurunya (Danu Rejo) yang saat itu dalam keadaan sakit parah. Setelah bertemu, keduanya kaget dan saling pandang agak lama. Dalam benak masing-masing, R.M. K.H.Muhammad Nur Alizen bergumam dalam hati, "Lho, inikan orang yang hadir dalam istikhrahku pada saat menjalankan ibadah haji beberapa waktu lalu." Setelah dipersilahkan duduk di kursi galar (kursi panjang dari bambu) Danu Rejo dengan suara yang agak berat karena sakit bercerita bahwa dalam istikhahnya Allah SWT memberi gambaran akan datang seorang Sunan/seorang alim dan akan menjadikan daerah ini aman dan maju dalam pendidikan agama. R.M. K.H. Muhammad Nur Alizen berkata bahwa gurunya, 
yaitu Danu Rejo, dalam istikharahnya pada saat menjalankan ibadah haji adalah Syekh Muhammad Sholeh/Mbah Sholeh". Musholla/surau angkring (mushola yang berbentuk panggung terbuat dari kayu, lantainya papan, temboknya terbuat dari anyaman bambu) diserahkan kepada R.M. K.H Muhammad Nur Alizen untuk memugar dan mengelolanya agar agama maju pesat di daerah Rejodanu. Akhirnya R.M. K.H Muhammad Nur Alizen memboyong keluarganya ke Rejodanu. Tidak begitu lama kemudian, Danu Rejo/Syekh Muhammad Sholeh/Mbah Sholeh wafat, dan dimakamkan satu lokasi dengat kedua saudaranya. Di perkirakan makam ketiga saudara tersebut yaitu Danu Ismoyo, Danu Ismadi, Danu Rejo berada di sebelah Barat makam sunan Rejodanu atau sebalah barat tangkis lama/tangkis makam.

Tangkis adalah tanggul untuk menangkis banjir. Semakin lama di Rejodanu semakin banyak santrinya, sesuai dengan amanah Syekh Muhammad Sholeh (Mbah Danu Rejo) akhirnya R.M. K.H Muhammad Nur Alizen dan masyarakat sekitar memberinyagelar Sunan Rejodanu. Karena waktu itu masih dalam masa penjajahan, maka keturunannya dan masyarakat menyembunyikan identitas dan makamnya.Lokasi masjid dan pondok pesantren Rejodanu sekarang sudah hancur/hilang dan sudah menjadi sungai. Sunan Rejodanu adalah seorang tokoh agama.Selain tokoh agama juga dikenal sebagai tokoh masyarakat. Sunan Rejodanu menguasai ilmu agama dan membimbing masyarakat tentang cara beribadah dan juga bercocok taman atau bertani. Sunan Rejodanu melepaskan gelarnya untuk sementara waktu karena saat itu adalah masa penjejahan. Para kyai diincar penjajah karena mereka adalah sumber ilmu. Sunan Rejodanu melepaskan gelarnya untuk sementara guna untuk mengelabuhi musuh.Iarela melepas gelar dan berhubungan dengan penjajah dengan syarat tidak diperbolehkan mengumpulkan massa. (Wawancara Ali Said).

\section{Peninggalan-Peninggalan Sejarah Situs Sunan Rejodanu}

Sunan Rejodanu menurut cerita para sesepuh beliau adalah prajuritnya Pangeran Diponegoro, setelah sampai di Pucangrejo beliau mensyiarkan agama Islam dan waktu itu pucangrejo itu terkenalnya dengan sebutan Rejodanu.Dahulu Sunan Rejodanu mempunyai banyak santri dan di situ dulu terdapat sebuah padepokan atau pondok pesanten. Makam sunan Rejodanu berada di tangkis baratnya sungai. Sungainya meluap pasti makamnya terkena banjir. Tetapi anehnya makam tersebut tidak tenggelam menurut cerita makamnya tersebut terkenal makam antik tengah sungai. Dan sunan Rejodanu pun sudah banyak keturunannya di Pucangrejo. Banyak peziarah dari luar kota yang ingin mendoakan sunan Rejodanu, setiap malam jumat banyak berdatangan. Dari pihak pemerintah desa akan segera merealisasikan anggaran dana untuk perawatan Sunan Rejodanu agar terlihat bagus dan para peziarah juga bisa berziarah secara nyaman. Lalu pemerintah desa juga mengupayakan 
segera melestarikan secara luas agar masyarakat luas dari luar provinsi pun juga tau bahwa disini ada Situs Makam Sunan Rejodanu. Menurut cerita para sesepuh terdahulu ada peninggalan yang mengganjal di hati masyarakat, sampai sekarang peninggalan tersebut masih simpang siaur dan masih menjadi bahan pembicaraan masyarakat setempat. Peninggalan tersebut berupa batu dan batu itu adalah batu kejen. Menurut masyarakat sekitar batu tersebut dipercaya bahwa itu adalah peninggalan Sunan Rejodanu dan ada juga yang tidak percaya akan hal itu, karena sampai sekarang belum ada penelitian tentang batu tersebut. dan anehnya batu tersebut dikeramatkan oleh masyarakat sekitar dan di taruh di depat punden Desa Pucangrejo. Batu tersebut dianggap keramat atau disakralkan oleh masyarakat sekitar, karena dahulu ada yang ingin mencuri batu tersebut tetapi batu tersebut kembali lagi ketempat semula. Jika di pikir secara logika kebanyakan orang tidak percaya halhal yang bersifat goib, tetapi masyarakat di situ mempercayai bahwa batu tesebut adalah batu kramat yang disakralkan. Kembali lagi menoleh kebelakang bahwa masyarakat Desa Pucangrejo adalah masyarakat jawa yang mempercayai bahwa kekuatan benda-benda keramat itu memang ada sejak zaman dahulu. Masyarakat Jawa pun mempercayai bahwa di setiap benda keramat ada yang menghuni di dalamnya atau ada penungunya.(Wawancara Satria,Kepala Desa Pujangrejo).

Makam Sunan Rejodanu dan adiknya yaitu R.M Tumenggung Muhammad Nur Ali Imron berada di Rejodanu, Desa Pucangrejo, Kecamatan Sawahan, Kabupaten Madiun, Provinsi Jawa Timur.Namun pada tahun 1988 makam R.M. Tumenggung Muhammad Nur Ali Imron dipindahkan ke makam Umum dusun Juron, Desa Pucangrejo. Makam Sunan Rejodanu dikenal dengan makam Antik Tengah Sungai. Peninggalan yang masih ada sampai saat ini adalah makam Sunan Rejodanu. Peninggalan yang lain berada di pinggir sungai yaitu sumur. Sumur tersebut tidak bisa dilihat jika sungai banjir dan airnya penuh. Dulu terdapat pesantren dan masjid dan disamping masjid ada makam. Sekarang masjid dan pesantren tersebut telah hancur karena banjir yang cukup besar. Situs Sunan Rejodanu sampai sekarang masih terawat dan terjaga dengan baik.Anak cucunya pun ikut merawat dan oleh berbagai kalangan masyarakat juga ikut merawat yang menziarahinya (Wawancara Ali Said).

\section{Potensi Situs Sunan Rejodanu Sebagai Wisata Sejarah dan Religi}

Pada dasarnya seluruh tempat religi mempunyai potensi yang berbeda-beda. Disebut Makam Antik Tengah Sungai karena pada wktu banjir besar masih terlihat makamnya seperti pulau kecil ditengah. Sampai sekarang masih ada pengunjung yang ingin berziarah ke makam Sunan Rejodanu.Sebagian besar pengunjung dan peziarah melakukan ziarah pada malam hari dan tidak ada jadwal khusus untuk ziarah, baik hari libur atau hari kerja (Wawancara Ali Said). Sebelum tahun 1970-an, Bengawan Madiun sering banjir, 
kadang-kadang dalam 1 tahun meningkat 3 sampai 4 kali banjir.Tetapi anehnya udara seperti menghindari makam. Konon, menurut tradisi lisan, makam Sunan Rejodanu dijaga oleh puluhan ribu jin yang dulunya telah ditundukkan kemudian menjadi santrinya. Sebelum tahun 2000 dari makam Sunan Rejodanu mendengar suara gemuruh orang mengaji di siang hari sebelum Dhuhur. Kadang-kadang terdengar suara gemuruh seperti orang shalawatan di malam hari dan kebanyakan yang mendengarkan adalah masyarakat Tiron dan sekitarnya. Dari generasi ke generasi, anak turun dan masyarakat di sekitarnya tidak ada yang berani mengunjungi komplek makam karena masyarakat dianggap angker. Sekitar tahun 1974 salah satu menantu Kyai Muhammad Ikhwan yaitu Kyai Abdus Salam dari Dungus, salah satu murid dari Al-Mursyid Prof, DR, K.H. Buya Musta'in Romli, Rejoso Peterongan, Jombang, diberi amanah oleh gurunya untuk babad dan nengembangkan tarekat serta menjadi Imam tarekat sekaligus Koordinator Thoriqoh Qodiriyah Wan Naqsyabandiyah se-Karesidenan Madiun. Iayang pertama kali mengajak untuk tawasul dan melaksanakan tahlil di makam Sunan Rejodanusetiap dua tahun sekali (setelah Shalat Idul Fitri dan Idul Adha serta pada malam-malam khusus).

Salah satu keturunannya, yaitu Soeroyo bin Mas Moelyadi melihat kondisi makam Sunan Rejodanu sangat memprihatinkan dan dikhawatirkan tergerus air sungai Madiun. Pada tahun 1990, ia mengamanahkan Drs Muhammad Thoyib Kedondong, agar makam Sunan Rejodanu dipagar keliling dan sebagian besar biaya ditanggungnya. Pada saat sungai Madiun banjir besar selama 4 hari, puncaknya pada tanggal 24 Desember 2007 dan arusnya sangat deras membelah makam Sunan Rejodanu. Semua tanaman yang biasa digunakan rumpun bambu dan makam tumbang Di sisi lain terlihat kabut putih tipis menyelimuti makam, seakan-akan melindungi makam dari amukan banjir. Fenomena tersebut dipotret oleh wartawan Kompas. Semua orang yang melihat langsung bertasbih dan akhirnya ada salah seorang yang menyebutnya Makam Antik Tengah Sungai (Ali Said. 2015).

Tradisi ziarah di Situs Makan Sunan Rejodanu sampai sekarang masih dilestarikan, bahkan lebih ramai pengunjungnya dari Madiun dan sekitarnya, khususnya pada malam Jum'at dan malam-malam tertentu harilibur.Hal ini mengindikasikan bahwa situs tersebut potensial sebagai wisata sejarah sekaligus juga mempelajari sejarahnya (wisata sejarah). Setiap lebaran idul fitri di dalam lingkaran rejodanu mengadakan istigosah di dekat makam tersebut.Dulu Dusun Pucangrejo ada dua bagian yaitu Rejodanu dan Pucanganom, dan pada akhirnya di jadikan sstu bernama Pucangrejo. Dahulu keduanya mempunyai pemerintahan sendiri-sendiri sebelum dijadikan satu. Lambat laun semakin banyak yang mendatangi makam sunan rejodanu, tidak lain berziarah mendoakan. Masyarakat juga ikut melestarikan cagar budaya situs Sunan Rejodanu tersebut merawat dan kadang ada kerja bakti 
membersihkan makam tesebut. (Wawancara Sudarso, Kepala Dusun). Apresiasi masyarakat terhadap situs sunan Rejodanu juga ikut serta dalam melestarikan situs agar terawatt dengan baik dan bagus. Masyarakat juga ikut membantu seperti menyumbangkan dana untuk pembangunan agar terlihat lebih rapi dan bersih. Harapan kedepan untuk kemajuan Situs Sunan Rejodanu tersebut adalah dari pemarintah khususnya yang bersangkutan dengan keagamaan juga ikut melestarikan situs tersebut dan masyarakat sekitar juga bisa mengelolanya dan dijadikan sebagi kemajuan ekonomi masyarakat sekitar. Contohnya seperti digunakan sebagi wisata religi atau wisata sejarah agar rame pengunjung masyarakat di sekitar situ juga bisa berjualan makanan untuk beristirahat setelah berziarah atau semacam bunga untuk berziarah (Wawancara Harto).

\section{B. Pembahasan}

Sunan Rejodanu berasal dari Rembang Jawa Tengah.Nama lengkapnya adalah Muhammad Nur Ali Zaen. Ia datang ke Madiun karena diutus oleh ibunya untuk mencari adiknya yang hilang, yaitu Muhammad Ali Imron. Muhammad Ali Imron hilang pasca perang Jawa. Ia adalah prajuritnya Diponegoro yang melarikan diri dari kejaran penjajah Belanda. Perang Diponegoro atau Perang Jawa merupakan salah satu peperangan yang sangat melegenda dalam perjuangan rakyat di Nusantara untuk melawanan penjajahan Belanda. Pengakuan atas Diponegoro juga mendapatkan penguat dari dunia internasional yang ditunjukkan dengan pengakuan UNESCO atas Babad Diponegoro (catatan pribadi kehidupan Diponegoro) sebagai warisan dunia (Tobroni, 2019). Sunan Rejodanu mendengar berita bahwa adiknya belajar ilmu agama di Madiun. Ia pun beliau langsung menuju Madiun dan ikut belajar ilmu agama. Sunan Rejodanu diutus oleh gurunya untuk melanjutkan belajar agama di tanah suci sembari menjalankan ibadah haji.Setelah kembali dari tanah suci diamanahi oleh gurunya untuk menyebarkan agama Islam dan diberigelar Sunan. Ia diamanahi oleh gurunya untuk mengelola pondok pesantren karena gurunya yakin bahwa Sunan Rejodanu mampu membawa perubahan besar untuk pondok tersebut.

Pondok tesebut pun banyak santrinya. Setelah berberapa tahun pondok tesebut hancur berserta masjidnya karena banjir yang sangat besar. Sunan Rejodanu adalah seorang tokoh agama. Selain tokoh agama juga dikenal sebagai tokoh masyarakat. Sunan Rejodanu menguasai ilmu agama dan membimbing masyarakat tentang cara beribadah dan juga bercocok tanam atau bertani. Sunan Rejodanu melepaskan gelarnya untuk sementara waktu karena saat itu adalah masa penjejahan. Para kyai di incar penjajah karena mereka adalah sumberilmu. Sunan Rejodanu melepaskan gelarnya untuk sementara karena mengelabuhi musuh. Ia rela melepas gelar dan berhubungan dengan penjajah dengan syarat tidak diperbolehkan mengumpulkan massa. Peninggalan Sunan Rejodanu yang tersisa adalah 
makam dan batu kejen yang di sakralkan oleh masyarakat setempat. Makam Sunan Rejodanu baru dikenal oleh masyarakat sekitar 5 tahunan ini.Makamnya dirahasiakan untuk menghin dari para penjajah atau oknum yang tak bertanggung jawab berbuat sesuatu yang aneh-aneh. Masyarakat sekitar berharap Situs Sunan Rejodanu tersebut bisa dikenal oleh masyarakat luas dan menjadi destinasi wisata sejarah dan wisata religi di Kabupaten Madiun, dan adanya kepedulian dari Pemkab Madiun untuk mengembangkan lebih luas lagi bahwa di Kecamatan Sawahan ada destinasi wisata religi yang nantinya akan membantu perekonomian warga sekitar. Masyarakat sekitar juga berharap adanya penelitian tentang batuk ejen yang sekarang masih menjadi misteri di lingkungan masyarakat sekitar desa Pucangrejo. Makam Sunan Rejodanu pun makin hari makin ramai oleh pengunjung peziarah.Mereka datang untuk mendoakan dan bersholawat di dekatnya makam sunan Rejodanu. Makam SunanRejodanuberada di sebelahbaratsungai, di sebelah baratnya lagi terdapat masjid. Makam Sunan Rejodanu dikenal dengan makam Antik Tengah Sungai. Para peziarah yang datangshalat di masjid tersebut.

Di area makam tersebut ada beberapa makam lainnya, yaitu makam isrit, anak, dan cucunya. Dulu makam adik Sunan Rejodanu berada di sekitar pemakaman sunan Rejodanu, tetapi dengan seiringnya waktu dipindah ke Dusun Juron DesaPucangrejo oleh anak cucunya pada tahun 1988. Peninggalan yang lain berada di pinggir sungai yaitu sumur. Sumur tersebut tidak bisa dilihat jika sungai banjir dan airnya penuh. Dahulu terdapat pesantren dan masjid dan disamping masjid ada makam. Sekarang masjid dan pesantren tersebut telah hancur karena banjir yang cukup besar. Peninggalan lainnya adalah batu kejen yang sekarang dijadikan benda sacral oleh masyarakat Desa Pucangrejo. Batu tersebut berada di berbatasan desa atara Desa Pucangrejo dan Krokeh. Batu tersebut sampai sekarang masih simpang siur kepercayaannya karena sampai sekarang belum ada penelitian tentang batu tersebut. Tetapi masyarakat setempat mempercayai batu tersebut juga peninggalan pada jamannya perang jawa dan tempat untuk menaruh batu tersebut di jadikan punden di Desa Pucangrejo dan di bersihkan saat ada adat bersih Desa.

Harapan masyarakat Desa Pucangrejo adalah ada kejelasan tentang batu tersebut dan bisa dikembangkan sebagai destinasi wisata juga seperti Wisata Religi Situs Sunan Rejodanu yang sekarang perlahan lahan bisa dikenal oleh masyarakat luas dari dalam kota maupun luar kota. Agar membantu perekonomian masyarakat sekitar lebih maju dan unggul dan mengurangi tingkat pengangguran. Situs Sunan Rejodanu sampai sekarang masih terawat dan terjaga dengan baik. Anak cucunya pun ikut merawat dan oleh berbagai kalangan masyarakat juga ikut merawat yang menziarahinya. Potensi situs Sunan Rejodanu sebagai wisata sejarah dan religi dapat menarik wisatawan datang mengunjungi situs Sunan 
Rejodanu. Pada dasarnya seluruh tempat religi mempunyai potensi yang berbeda-beda. Makam tersebut memiliki nama lain yang menarik perhatian, yaitu MakamAntik Tengah Sungai karena pada waktu banjir besar masih terlihat makamnya seperti pulau kecil ditengah. Sampai sekarang masih ada pengunjung yang ingin berziarah ke makam Sunan Rejodanu. Sebagian besar pengunjung dan peziarah melakukan ziarah pada malam hari dan tidak ada jadwal khusus untuk ziarah, baik hari libur atau hari kerja. Tradisi ziarah masih kuat di Situs Makan Sunan Rejodanu khususnya pada malam Jum'at dan malam-malam tertentu harilibur.Hal ini mengindikasikan bahwa situs tersebut potensial sebagai wisata sejarah sekaligus juga mempelajari sejarahnya (wisata sejarah). Potensi pariwisata berbasis sejarah budaya merupakan salah satu aset yang memiliki potensi untuk dikembangkan oleh setiap daerah (Adi, dkk). Hal ini tidak hanya terkait dengan kepentingan untuk dapat memacu pendapatan daerah, tapi juga urgensi terhadap pengembangan ekonomi daerah.

Argumen yang mendasari karena mata rantai dari kepariwisataan cenderung sangat kompleks dan setiap daerah memiliki karakteristik yang berbeda sehingga hal ini menjadi keunikan tersendiri yang membedakan dengan daerah yang lain. Oleh karena itu, daerah yang mampu mengembangkan potensi wisata, termasuk wisata sejarah budayanya maka akan memperoleh kemanfaatan dari kepariwisataan (Waskito \& Saputro, 2017). Demikian pula tradisi istigosah di dekat makam tersebut. Keragaman budaya dan religi di Indonesia berpotensi untuk dikembangkan menjadi wisata (ARN, 2015). Destina wisata religi perlu dikelola dengan serius, karena saat ini kedua jenis wisata tersebut belum digarap secara optimal. Hal tersebut perlu pengelolaan destinasi dengan baik, pengemasan produk wisata dan promosi pada segmen wisata minat khusus (Hariyanto, 2016). Masyarakat aktif dalam melestarikan situs agar terawatt dengan baik. Masyarakat juga ikut membantu menyumbangkan dana untuk pembangunan agar terlihat lebih rapi dan bersih. Masyarakat bekerjabakti membersihkan makam. Dukungan masyarakat tersebut penting agar Situs Sunan Rejodanu dapat menjadi wisata religi atau wisata sejarah yang ramai pengunjung. Masyarakat sekitar juga bisa membuka peluangusaha dengan berjualan berbagai makanan bagi para perziarah.

\section{Kesimpulan}

Sunan Rejodanu bernama asli Muhammad Nur Ali Zaenasal Rembang Jawa Tengah. Sunan Rejodanu datang ke Madiun untuk mencari adiknya yang hilang pasca perang Jawa, yaitu Muhammad Ali Imron, seorang prajurit Pangeran Diponegoro yang melarikan diri dari kejaran penjajah Belanda. Di Madiun, Sunan Rejodanu belajar dan menyebarkan agama Islam dan diberi gelar Sunan. Oleh gurunya ditugasi mengelola pondok pesantren dan 
mampu membawa perubahan besar,namun pondok tesebut hancur beserta masjidnya karena banjir bandang. Sunan Rejodanu adalah sosok ulama yang menguasai ilmu agama yang membimbing masyarakat tentang cara beribadah dan juga bercocok tanam atau bertani. Peninggalan Sunan Rejodanu yang tersisa adalah makam, batu kejen, yang disakralkan oleh masyarakat setempat,dan sumur. Makam Sunan Rejodanu dikenal dengan makam Antik Tengah Sungai karena pada saat alir meluap masih terlihat makamnya seperti pulau kecil di tengah. Situs Sunan Rejodanu sampai sekarang masih terawat dan dijaga dengan baik oleh anak cucunya dan masyarakat.Situs Sunan Rejodanu dapat menjadi wisata sejarah dan religi yang menarik wisatawan datang mengunjunginya. Selain sosok dan perjalanan hidup Sunan Rejodanu, makamnya juga memiliki nama lain yang menarik perhatian, yaitu Makam Antik Tengah Sungai. Tradisi keagamaan masih kuat di Situs Makan Sunan Rejodanu. Hal ini mengindikasikan bahwa situs tersebut potensial sebagai wisata sejarah untuk mempelajari sejarahnya dan wisata religi. Dukungan masyarakat yang besar menjadi penting agar Situs Sunan Rejodanu dapat menjadi wisata religi atau wisata sejarah yang ramai pengunjung. Masyarakat sekitar juga bisa membuka peluangusaha dengan berjualan berbagai makanan bagi para peziarah.

\section{Daftar Pustaka}

Asisten Deputi Pengembangan Wisata Budaya Deputi Bidang Pengembangan Industri dan Kelembagaan Kementerian Pariwisata.(2018). Pedoman Pengembangan Wisata Sejarah dan Warisan Budaya. Woderful Indonesia .

Novi Triana Habsari. (2016). Situs Ngurawan Sejarah dan Potensinya Sebagai Sumber Sejarah Lokal. Agastya.http://e-jurnal.unipma.ac.id/index.php/ JA/article/view/881/794.Diakses 30 Maret 2020.

Pemerintah Kabupaten Daerah Tingkat II Madiun. (1980). Sejarah Kabupaten Madiun.

Pupu Saeful $\quad$ Rahmat. $2009 . \quad$ Penelitian Kualitiatif. https://www.google.com/search?q=pupu+seful+rahmat+penelitian+kualitatif\&oq= pupu+sae\&aqs=chrome.1.69i57jOl2.13268j1j\&cliant=ms-androidvivo\&sourceid=chrome-mobile\&ie=UTF-8 di akses 8 April 2020

Rasyid. (2019). Pengertian Wisata Religi Menurut Para Ahli. https://santrinow.com/2019/03/pengertian-wisata-religi-menurut-para-ahli.html. diakses 7 April 2019

Saputra.(2019). Pengertian Kualitatif.https://materibelajar.co.id/pengertian-kualitatif/ diakses 15 April 2020

SaidAli., S. (2015). SilsilahSunanRejodanu. Tidak diterbitkan.

Sidiq.(2018). Data Primer dan Data Sekunder.https://www.google.com/amp/ sosiologis.com/data-primer-dan-data-sekunder/amp, diakses 15 April 2020

Soebijantoro \& Ike Fuadillah.(2016). Situs Ngurawan Kecamatan Dolopo Kabupaten Madiun (Latar Sejarahdan Upaya Plestariannya).Agastya.http://ejurnal.unipma.ac.id/index.php/JA/article/view/1041/926. diakses 30 Maret 2020. 